\title{
Effect of Ozone Application on the Fungal Count and Lipid Quality of Peanut Grains
}

\author{
Jessica Cristina Urbanski Laureth ${ }^{1}$, Divair Christ ${ }^{1}$, Diandra Ganascini ${ }^{1} \&$ Silvia Renata Machado Coelho ${ }^{1}$ \\ ${ }^{1}$ Graduate Program, Master's and Doctorate in Engineering of Agricultural, Western Paraná State University, \\ Cascavel, Brazil
}

Correspondence: Jessica Cristina Urbanski Laureth, Graduate Program, Master's and Doctorate in Engineering of Agricultural, Western Paraná State University, Universitária, 2069, Jardim Universitário, 85819-110, Cascavel, Paraná, Brazil. Tel: 55-453-220-3153. E-mail: jeh_urbanski@hotmail.com

Received: January 10, 2019

Accepted: February 7, $2019 \quad$ Online Published: April 15, 2019

doi:10.5539/jas.v11n5p271

URL: https://doi.org/10.5539/jas.v11n5p271

\begin{abstract}
Peanut is susceptible to fungal contamination at all stages of its production chain, which can lead to aflatoxin production, which can cause serious health problems for consumers. In this sense, post-harvest ozonation of grains has the potential to reduce contaminant microorganisms, but it may cause oxidative damage, degrading organic constituents. Thus, factors influencing the reduction of fungal contamination by gaseous ozone in peanuts (grains and grains in pods) and changes in lipid and oil quality of grain were investigated. The analyzed variables were total fungi count, electrical conductivity, peroxide index, and 2-thiobarbituric acid test. Ozone concentration $(10,30$, and $50 \mathrm{ppm})$ and ozonation time (30,45, and 60 minutes) significantly affected fungal count $(\mathrm{p}<0.05)$. The maximum fungal reductions were $75.79 \%$ for grains and $82.66 \%$ for grains in pods at a concentration of $50 \mathrm{ppm}$ and exposure of 60 minutes. The electrical conductivity of exudates was affected by ozone concentration. There was degradation of lipids at a cellular level, but no differences were observed in the peroxide index of treated grains.
\end{abstract}

Keywords: ozone gas, peanut pod, peanut oil, lipid peroxidation

\section{Introduction}

Peanut (Arachis hypogaea L.) is consumed worldwide because of its high nutritional value, as a source of lipids and proteins, but is susceptible to fungal contamination, which can produce aflatoxins (Martins et al., 2017; Power et al., 2017; Wang, Lien, \& Ling, 2018). The fungal species Aspergillus flavus and Aspergillus parasiticus are the main producers of mycotoxins in peanuts. The species $A$. flavus produces the aflatoxins $\mathrm{B}_{1}$ and $\mathrm{B}_{2}$ and $A$. parasiticus is able to produce the aflatoxins $\mathrm{G}_{1}$ and $\mathrm{G}_{2}$, presenting a highly toxic character for human and animal health (Sahab, Hassanien, El-Nemr, Abdel-Alim, \& Abdel-Wahhab, 2013).

Many methods have been used to reduce or remove these fungal species, but the consolidation of a highly effective method is far from being defined (Granella, Christ, Werncke, Bechlin, \& Coelho, 2018). The methods involve chemical (Saalia \& Phillips, 2011), physical (Mao et al., 2016), and biological processes (Chen, Kong, Chi, Shan, \& Guan, 2015), but are not practical and are based on laboratory analysis, not large-scale.

Ozone $\left(\mathrm{O}_{3}\right)$ application or ozonation is a new, low-cost, and environmentally correct methodology (Diao, Wang, $\mathrm{Li}, \&$ Wang, 2018), which can be used in the processing industry. Ozone has been used and shown to be effective in reducing and degrading fungi and mycotoxins in peanuts (Alencar, Faroni, Soares, Silva, \& Carvalho, 2012; Chen et al., 2014; Diao, Hou, Chen, Shan, \& Dong, 2013).

Although ozone is widely used as an antimicrobial agent, in some cases it can promote lipid oxidation, protein modifications, changes in grain color (Alencar, Faroni, Soares, Carvalho, \& Pereira, 2011), and development of undesirable aromas (Mendez, Maier, Mason, \& Woloshuk, 2003), reducing protein and lipid contents (Sahab et al., 2013) and directly influencing the nutritional and sensory quality of the product (Tiwari et al., 2010). In addition, its efficiency depends on factors such as food matrix, ozone concentration, and exposure time (Christ, Savi, \& Scussel, 2016).

Therefore, it is necessary to verify the effect of ozonation in order to reduce fungal contamination and not alter the organic cell components of grains. 
In the peanut processing industry, pods coming from the field are dried in order to facilitate the removal of grains. Pods or grains with a low water content can be stored until processed. Thus, our study sought to evaluate the effect of ozonation not only on grains but also on grains in the pod, which naturally have a physical barrier.

The studies reported the application of ozone in peanut grains, so our results can help the processing industry in the decision to apply the gas in grains or grains in the pod, in a way that facilitates the industrial process.

Thus, the main objective of this study was to evaluate the different ozonation conditions in peanuts (grains and grains in pods) under levels of fungi reduction, electrical conductivity, peroxide index, and 2-thiobarbituric acid test.

\section{Material and Methods}

\subsection{Samples}

Samples of peanuts (grains and grains in pods) (approximately $8 \%$ wb water content) of the variety Runner Granoleico, obtained from the commercial production in northwestern Paraná (with averages of temperature and precipitation during planting and harvesting of $27{ }^{\circ} \mathrm{C}$ and $146 \mathrm{~mm}$, respectively,), were stored at $7{ }^{\circ} \mathrm{C}$ until the beginning of the tests. The experiment was conducted at the Laboratory of Quality Control of Agricultural Products (LACON) of the Western Paraná State University (UNIOESTE), Campus of Cascavel, Paraná, Brazil.

\subsection{Ozonation System}

Ozone $\left(\mathrm{O}_{3}\right)$ gas was obtained by a Philozon SKID-20 industrial ozonator, with measurement of the ozone concentration generated and capacity of $20 \mathrm{~g} \mathrm{O}_{3} \mathrm{~h}^{-1}$ through a corona discharge effect with forced air-cooling of $2 \mathrm{~L} \mathrm{~min}^{-1}$. The input used for ozone production was pure oxygen in a PSA (pressure swing adsorption) system. Samples with $200 \mathrm{~g}$ per replicate of pods and grains were packed in a support (50 L capacity) with flow and pressure control in the inlet and outlet and the generated $\mathrm{O}_{3}$ was injected. Ozone gas was introduced into the system at different concentrations and times, according to experimental design.

\subsection{Experimental Design}

The experimental design was a central composite design (CCD) with two factors, i.e., ozone concentration (X1) and application time (X2). Each factor in the experiment was established and coded at three levels, i.e., lower $(-1)$, medium (0), and higher (+1), with values of X1 of 10, 30, and $50 \mathrm{ppm}$ and $\mathrm{X} 2$ of 30, 45, and $60 \mathrm{~min}$. Seven tests were performed, including three replications at the central point (Table 1).

Table 1. Matrix of the central composite design with the actual and coded values

\begin{tabular}{lll}
\hline Test & Ozone concentration $(\mathrm{ppm})$ & Application time $(\mathrm{min})$ \\
\hline 1 & $10(-1)$ & $30(-1)$ \\
2 & $50(+1)$ & $30(-1)$ \\
3 & $10(-1)$ & $60(+1)$ \\
4 & $50(+1)$ & $60(+1)$ \\
5 & $30(0)$ & $45(0)$ \\
6 & $30(0)$ & $45(0)$ \\
7 & $30(0)$ & $45(0)$ \\
\hline
\end{tabular}

The total fungal count, electrical conductivity, peroxide index, and 2-thiobarbituric acid test were selected as dependent variables of the process. The results were analyzed using the software Statistica 10 (StatSoft Inc., Tulsa, OK, USA). The significance test and analysis of variance (ANOVA) were used to evaluate the quality of fit of the model from Equation (1):

$$
\hat{Y}=b_{0}+b_{1} X_{1}+b_{2} X_{2}+b_{12} X_{1} X_{2}
$$

where, $\hat{Y}$ is the estimated response, $b_{0}$ is the intercept term, $b_{1}$ and $b_{2}$ are the coefficients of linear terms, b12 is the coefficient of the interaction term, and $\mathrm{X}_{1}$ and $\mathrm{X}_{2}$ are the factors.

The coefficient of determination $\left(\mathrm{R}^{2}\right)$ was determined for the model and the model accuracy was established.

Three control samples were used (not included in the CCD). 


\subsection{Analysis}

\subsubsection{Total Fungal Count and Identification}

Ozonized peanut samples were analyzed for the evaluation of the effects of ozonation on fungal decontamination, as in Beuchat and Cousin (2001). Samples of $25 \mathrm{~g}$ were transferred to an Erlenmeyer flask containing $225 \mathrm{~mL}$ of peptone saline solution $(0.1 \%)$. The samples were homogenized for 60 seconds, corresponding to the dilution $10^{-1}$. From this dilution, dilutions $10^{-2}$ and $10^{-3}$ were prepared using test tubes containing $9 \mathrm{~mL}$ of peptone saline solution $(0.1 \%)$. Aliquots of $0.1 \mathrm{~mL}$ were plated on an acidified (10\% tartaric acid) potato dextrose agar surface and then incubated for five days at $25{ }^{\circ} \mathrm{C}$. After this period, the colonies were counted and the results expressed as $\mathrm{CFU} \mathrm{g}{ }^{-1}$ of grains.

For identification of fungi the direct plating method on filter paper was used. The beans were individually arranged on layers of filter paper dampened inside containers with transparent lids. Then, they were placed in incubation chamber for 24 hours at $20 \pm 2{ }^{\circ} \mathrm{C}$ in a regime of 12 hours of light and 12 hours of darkness. Subsequently, the plates containing the beans were stored in a freezer $\left(-20^{\circ} \mathrm{C}\right)$ for 24 hours. At the end of the freezing period, the plates were again returned to the incubation chamber, under the same conditions as before, for a further 5 days. After the entire incubation period, the samples were examined under an optical microscope for the identification of fungal structures (MAPA, 2009).

\subsubsection{Electrical Conductivity}

Three replications of 50 grains were used per treatment. Samples were pre-weighed on an analytical balance, placed in plastic containers $(200 \mathrm{~mL})$ with $75 \mathrm{~mL}$ of deionized water, and maintained at $25^{\circ} \mathrm{C}$ for 24 hours. The electrical conductivity of the solution was determined using a conductivity meter (Vieira, Tekrony, Egli, \& Rucker, 2001). The results were expressed as $\mu \mathrm{S} \mathrm{cm}^{-1} \mathrm{~g}^{-1}$.

\subsubsection{Peroxide Index}

Ozonized peanut grains were submitted to cold pressing for oil extraction (10 to $50 \mathrm{kN})$. Oil samples were analyzed according to the standards AOCS (2009), Cd 8-53. The peroxide index (PI) was calculated by Equation (2):

$$
P I=[N \cdot f \cdot 1000 \cdot(V a-V s)] / m
$$

where, $\mathrm{N}$ is the normality of the sodium thiosulphate solution $\left(\mathrm{Na}_{2} \mathrm{~S}_{2} \mathrm{O}_{3}\right)$, $\mathrm{f}$ is the correction factor of the $\mathrm{Na}_{2} \mathrm{~S}_{2} \mathrm{O}_{3}$ solution, $\mathrm{Va}$ is the volume of standard $0.1 \mathrm{~N} \mathrm{Na}_{2} \mathrm{~S}_{2} \mathrm{O}_{3}$ spent on sample titration $(\mathrm{mL})$, Vs is the volume of standard $0.1 \mathrm{~N} \mathrm{Na}_{2} \mathrm{~S}_{2} \mathrm{O}_{3}$ spent on the titration without sample $(\mathrm{mL})$, and $\mathrm{m}$ is the sample mass $(\mathrm{g})$.

\subsubsection{2-thiobarbituric Acid Test}

Ozonized samples of peanut grains and oil were used to perform the 2-thiobarbituric acid test (TBA). Samples of $0.25 \mathrm{~g}$ were homogenized in $2 \mathrm{~mL}$ of $0.1 \%$ trichloroacetic acid (TCA). The homogenized was centrifuged for 10 min at $10,000 \mathrm{rpm}\left(4{ }^{\circ} \mathrm{C}\right)$. The supernatant was collected $(250 \mu \mathrm{L})$ and mixed with $3 \mathrm{~mL}$ of $0.5 \%$ TBA solution and $20 \%$ TCA solution, then incubated at $95{ }^{\circ} \mathrm{C}$ for 35 minutes for color development. The reaction was stopped by cooling and lipid peroxidation was determined at $535 \mathrm{~nm}$ and $600 \mathrm{~nm}$ in a spectrophotometer. The results were expressed in mg of malonaldehyde (MA) kg of fresh mass (FM) (Silva, Borges, \& Ferreira, 1999) using the extinction coefficient of $1.56 \times 10^{-5} \mathrm{~cm}^{-1}$ (Michaowicz, Posmyk, \& Duda, 2009).

\subsubsection{Water Content of Grains}

The water content was determined by a forced air circulation oven at $105 \pm 1^{\circ} \mathrm{C}$ for 24 hours from three samples of $25 \mathrm{~g}$ of seeds for each replication (MAPA, 2009). The values were expressed as the percentage of wet basis $(\%, w b)$.

\section{Results and Discussion}

\subsection{Effect of Ozonation on Total Fungal Count}

Fungi of the genus Aspergillus (A. flavus and A. parasiticus), Rhizopus, Cladosporium, and Penicillium were identified in the peanut samples.

For calculating the fungal reduction, the total counts of control samples were used as a reference, corresponding to $9.5 \times 10^{-1} \mathrm{CFU} \mathrm{g}^{-1}$ for peanut grains and $7.9 \times 10^{-2} \mathrm{CFU} \mathrm{g}^{-1}$ for peanut grains in the pod.

The effects of each selected independent variable, in addition to its interactions with the levels of \% of fungal reduction, evaluated after grain ozonation were studied using the central composite design (CCD).

The Pareto diagram shown in Figure 1 presents the terms considered significant by the t-test for the $\%$ of fungal 
reduction after the ozonation process.

A

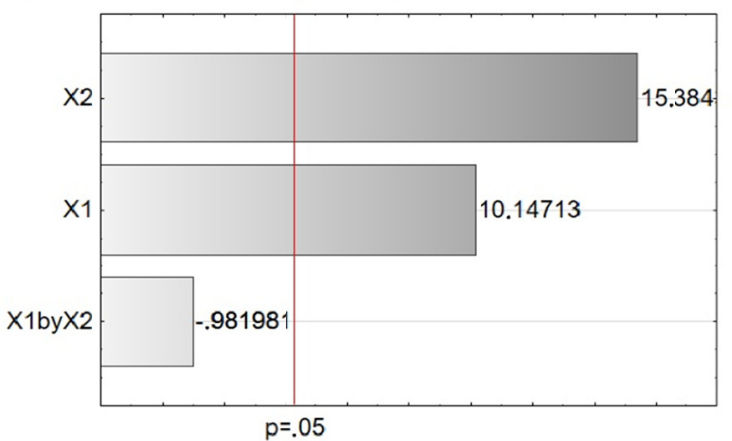

B

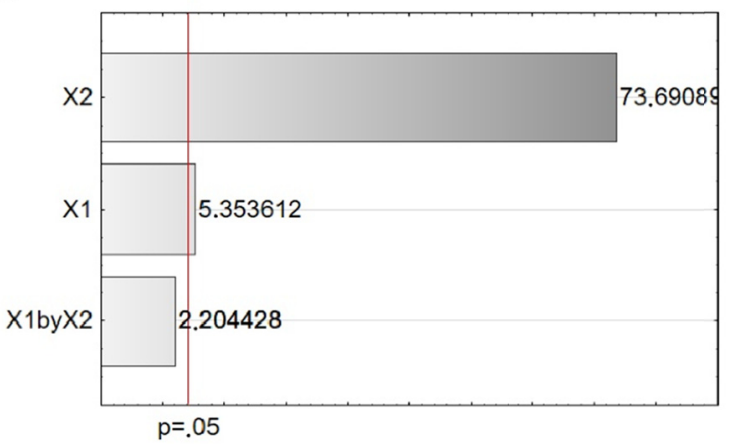

Figure 1. Pareto graphs of the $\%$ of fungal reduction after the ozonation process for peanut grains (A) and peanut grains in the pod (B)

The factors application time and $\mathrm{O}_{3}$ concentration presented a positive influence on the reduction of the fungal count, and the factor exposure time to ozone had a higher influence because the longer the ozonation time and ozone concentration, the higher the reductions. The interaction of variables did not show a significance under the experimental conditions used in this study $(\mathrm{p}<0.05)$.

Concentrations and ozonation times used in fungal reduction are varied in the literature. Abdel-Wahhab et al. (2011) used concentrations of 20,40 and 50 ppm and times of 5, 10 and 5 minutes, respectively, to decrease total fungal and aflatoxin counts in peanut pods and grains, and verified that the treatments significantly reduced the dependent variables.

In this study, the variables $\mathrm{O}_{3}$ exposure time and $\mathrm{O}_{3}$ concentration positively influenced fungal reduction. Alencar et al. (2012) reported that higher reductions in fungal counts occurred when the period of exposure to ozone was increased. According to Mendez et al. (2003), this occurs because ozone moves slowly through the grain layer. At the beginning of ozonation, $\mathrm{O}_{3}$ reacts with the grain mass and is rapidly decomposed. In its second phase, $\mathrm{O}_{3}$ moves freely through the grains with little degradation. $\mathrm{O}_{3}$ reacts faster with the whole grain mass when higher concentrations are used.

Thus, the results obtained in this study can be attributed to a high oxidative power of the gas. According to Cullen, Tiwari, O'Donnell and Muthukumarappan (2009), the inactivation of microorganisms by ozone is mainly due to the rupture of the cell envelope and subsequent dispersion of cytoplasmic constituents.

Equations (3) and (4) describe linear CCD response surface models fitted to the fungal reduction data for peanut grains and peanut grains in pods:

$$
\begin{aligned}
& \hat{Y}=51.58+8.16 X 1+12.37 X 2 \\
& \hat{Y}=66.86+1.07 X 1+14.81 X 2
\end{aligned}
$$

$\mathrm{R}^{2}$ was used to evaluate the accuracy of the regression equation. The models presented $\mathrm{R}^{2}$ values of $0.82(1)$ and 0.99 (2), indicating a good level of prediction accuracy of the model.

The results of the significance test and ANOVA of the regression equation model (Table 2) presented a statistically significant $p$-value at $95 \%$ confidence level $(\mathrm{p}<0.05)$. The test did not present a lack of fit, assuming normality, independence, and homoscedasticity of the residual variance. 
Table 2. Significance test for the regression coefficients and ANOVA

\begin{tabular}{|c|c|c|c|c|c|}
\hline Source of variation & Sum of squares & $\mathrm{DF}$ & Mean square & $\mathrm{F}$ & F tab \\
\hline \multicolumn{6}{|l|}{$A$} \\
\hline Regression & 878.12 & 2 & 439.06 & 9.03 & 4.32 \\
\hline Residual & 194.46 & 4 & 48.62 & & \\
\hline Lack of fit & 189.29 & 2 & 94.64 & 36.61 & 9 \\
\hline Pure error & 5.17 & 2 & 2.59 & & \\
\hline Total & 1072.58 & 6 & & & \\
\hline \multicolumn{6}{|l|}{$\ddot{B}$} \\
\hline Regression & 881.99 & 2 & 441.00 & 468.63 & 4.32 \\
\hline Residual & 3.76 & 4 & 0.94 & & \\
\hline Lack of fit & 3.44 & 2 & 1.72 & 10.65 & 9 \\
\hline Pure error & 0.32 & 2 & 0.16 & & \\
\hline Total & 885.75 & 6 & & & \\
\hline
\end{tabular}

Note. A: Means of fungal reduction of peanut grains after the ozonation process; B: Means of fungal reduction of peanut grains in pod after the ozonation process.

Figure 2 shows the graph of estimated values in relation to observed values. Treatments show that the largest reduction in fungal counts in both evaluations was achieved using the highest $\mathrm{O}_{3}$ concentration $(50 \mathrm{ppm})$ and the longest $\mathrm{O}_{3}$ exposure time $(60 \mathrm{~min})$. The reductions were respectively $75.79 \%$ and $82.66 \%$ for grains and grains in pod.
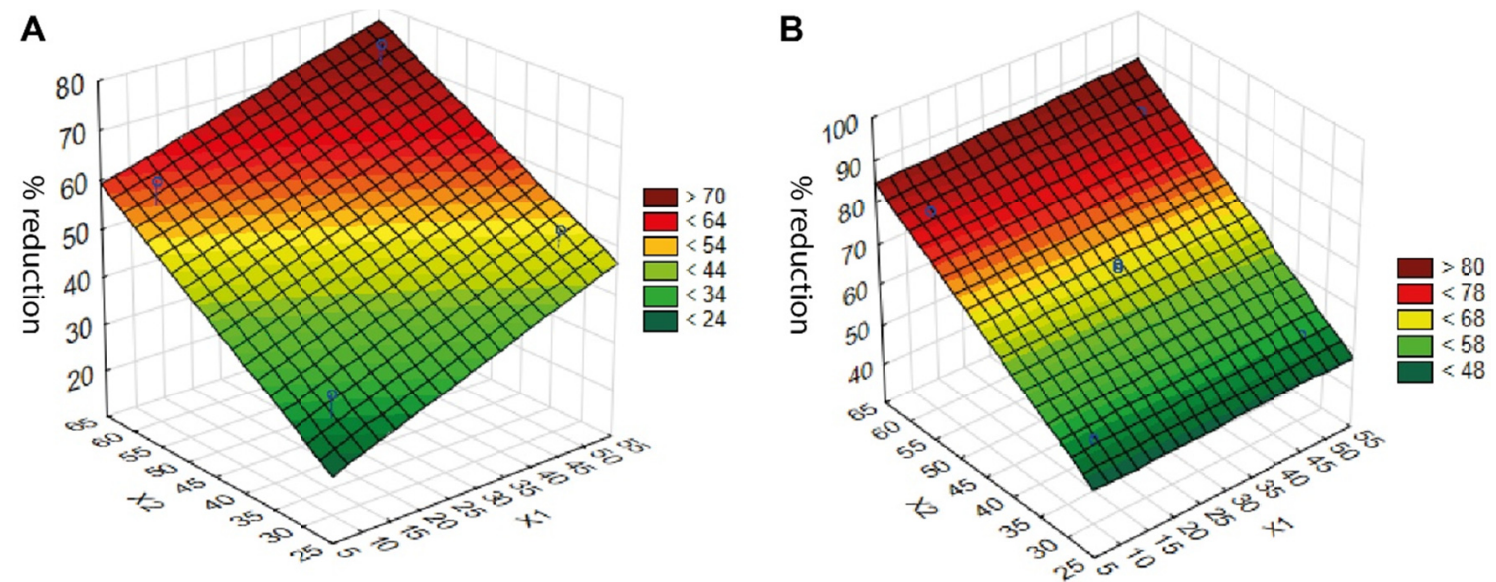

Figure 2. Graph of the fungal reduction (\%) after the ozonation process in peanut grains (A) and peanut grains in pod (B)

Ozonized grains in pod presented a higher fungal reduction when compared to ozonized grains, showing the gas passage through the porous medium of the peel. Figueiredo Neto, Dantas, Silva, Olivier, and Silva (2012) demonstrated a thirty-fold lower load loss for the air passage through a layer of peanut pods in relation to a soybean layer. The results of fungal reduction of grains in pods can also be explained by higher initial values of water content in grains (1.52\% more water). Khadre, Yousef, and Kim (2001) reported that the presence of water in grains can accelerate ozone decomposition and thus the production of oxidizing radicals capable of reacting rapidly with organic compounds. Thus, ozone uses water content as a transport vehicle.

\subsection{Effect of Ozonation on Electrical Conductivity}

In this study, the variable electrical conductivity was used because it is directly related to cell membrane integrity since poorly structured membranes and damaged cells are associated with the deterioration process (Heslehurst, 1988).

Thus, the electrical conductivity of exudates after the ozonation process was studied from the effects of each 
selected independent variable, as well as from its interactions, using the central composite design. Figure 3 represents the Pareto diagram showing the terms considered by the ANOVA test.

A

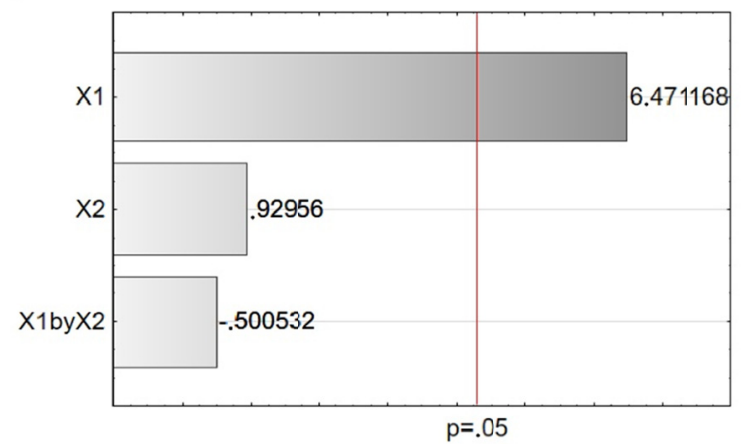

B

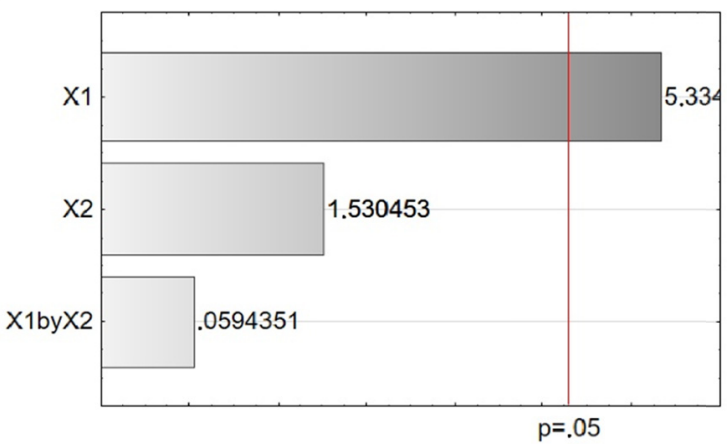

Figure 3. Pareto diagram of ozonation factors for electrical conductivity $\left(\mu \mathrm{Sm}^{-1} \mathrm{~g}^{-1}\right)$ in peanut grains (A) and peanut grains in pods (B)

The results showed that $\mathrm{O}_{3}$ concentration was considered significant $(\mathrm{p}<0.05)$ in the samples of grains and grains in pod. The highest values of electrical conductivity in both evaluations were obtained using a higher $\mathrm{O}_{3}$ concentration $(50 \mathrm{ppm})$ and a longer $\mathrm{O}_{3}$ exposure time $(60 \mathrm{~min})$.

The highest observed values were 38.16 and $47.85 \mu \mathrm{S} \mathrm{cm}^{-1} \mathrm{~g}^{-1}$ for grains and grains in pods, respectively. When compared to the control (36.84 and $45.20 \mu \mathrm{S} \mathrm{cm}^{-1} \mathrm{~g}^{-1}$ for grains and grains in pod, respectively), the values showed differences of $1.32 \mu \mathrm{S} \mathrm{cm}^{-1} \mathrm{~g}^{-1}$ for grains and $2.65 \mu \mathrm{S} \mathrm{cm}^{-1} \mathrm{~g}^{-1}$ for grains in pod. This occurred because the standard error was low, which led to this significant difference.

Rozado, Faroni, Urruchi, Guedes, and Paes (2008) also observed a significant increase in the electrical conductivity of the solution containing the corn grains that had been exposed to the gaseous ozone at a concentration of $50 \mathrm{ppm}$ for $264 \mathrm{~h}$. The authors classified this deterioration as moderate. However, Alencar et al. (2011) did not find significant variation in peanut grains through the interaction of the ozone gas concentration (13 and $\left.21 \mathrm{mg} \mathrm{L}^{-1}\right)$ and exposure periods $(0$ and $96 \mathrm{~h}$ ) and these two factors when analyzed separately.

The linear CCD response surface models fitted to the electrical conductivity data for peanut grains and peanut grains in pod are described in Equations (5) and (6):

$$
\begin{aligned}
& \hat{Y}=36.89+0.90 X 1 \\
& \hat{Y}=45.89+1.79 X 1
\end{aligned}
$$

$\mathrm{R}^{2}$ was used to evaluate the accuracy of the regression equation. The models presented $\mathrm{R}^{2}$ values of $0.75(1)$ and 0.80 (2), indicating a good level of prediction accuracy of the model.

\subsection{Effect of Ozonation on the Peroxide Index}

The peroxide index determines the hydroperoxides, which are primary oxidation products. Their presence is an indication of the beginning of oil deterioration.

The peroxide index of the oil extracted from the ozonized samples did not change significantly due to the interaction $\mathrm{O}_{3}$ concentration and time, as well as when they are analyzed separately $(\mathrm{p}<0.05)$.

The average values remained below $10 \mathrm{mEq} \mathrm{kg}^{-1}$, which is the limit established in Brazil (ANVISA, 1999) and Codex Alimentarius (FAO, 1999) for the commercialization of crude peanut oil.

Similar results were obtained by Alencar et al. (2011) in ozonized peanut grains at concentrations of 13 and 21 $\mathrm{mg} \mathrm{L}{ }^{-1}$ for up to $96 \mathrm{~h}$, and by Chen et al. (2014) in ozonized grains at a concentration of $6 \mathrm{mg} \mathrm{L}^{-1}$ for 30 minutes.

\subsection{TBA}

This parameter is based on the reaction of the thiobarbituric acid with hydroperoxide decomposition products. One of the main products formed in the oxidative process is malonaldehyde (MA), an aldehyde with 3 carbon atoms, besides the 4-hydroxyalkenes, 2,4-alkadienes, and the 2-alkenes, lipid oxidation products (Silva et al., 1999; Nawar, 1996). The results of the TBA test for ozonized grain and peanut oil samples are shown in Table 3. 
Table 3. 2-thiobarbituric acid test in samples of ozonized peanut oil and grain

\begin{tabular}{|c|c|c|c|c|c|}
\hline \multirow{2}{*}{ Concentration } & \multirow{2}{*}{ Time } & \multicolumn{2}{|c|}{ Grain (mg MA kg FM) } & \multicolumn{2}{|c|}{ Oil (mg MA kg FM) } \\
\hline & & Grain & Pod & Grain & Pod \\
\hline 10 & 30 & 255.90 & 193.91 & 16.00 & 12.30 \\
\hline 10 & 60 & 208.30 & 180.20 & 15.00 & 13.90 \\
\hline 50 & 30 & 276.20 & 222.22 & 29.40 & 17.60 \\
\hline 50 & 60 & 254.80 & 159.19 & 12.30 & 10.70 \\
\hline 30 & 45 & 220.10 & 229.20 & 10.10 & 11.80 \\
\hline 30 & 45 & 214.70 & 221.50 & 10.10 & 11.20 \\
\hline 30 & 45 & 210.50 & 226.80 & 11.80 & 10.70 \\
\hline Control & & 176.80 & 150.10 & 8.00 & 9.60 \\
\hline
\end{tabular}

Figure 4 represents the Pareto diagram that shows the terms considered by the ANOVA test. The results showed that the time and $\mathrm{O}_{3}$ concentration were considered significant $(\mathrm{p}<0.05)$ in grain samples. For oil samples, time and the interaction were considered significant $(\mathrm{p}<0.05)$, presenting a negative interaction.

A1

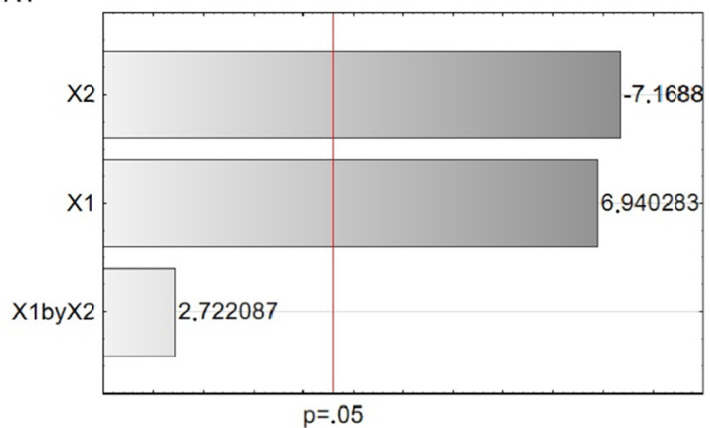

$\mathrm{A} 2$

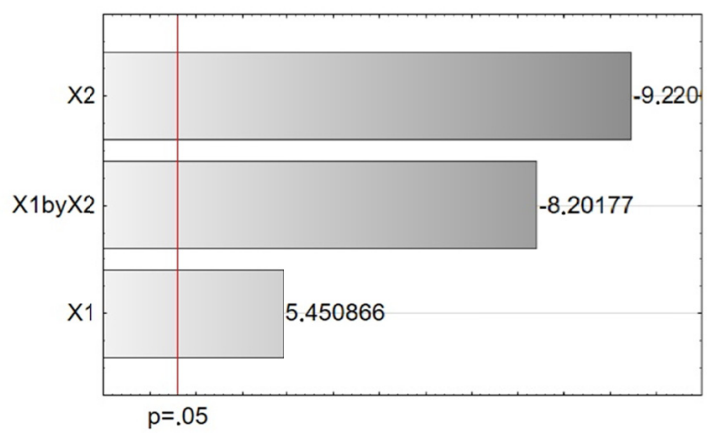

B1

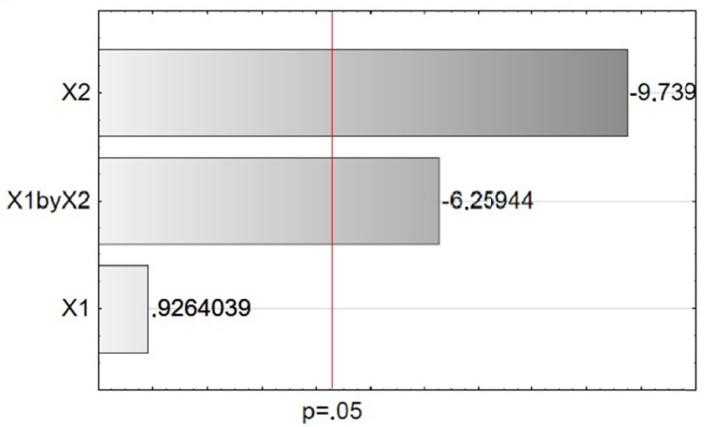

B2

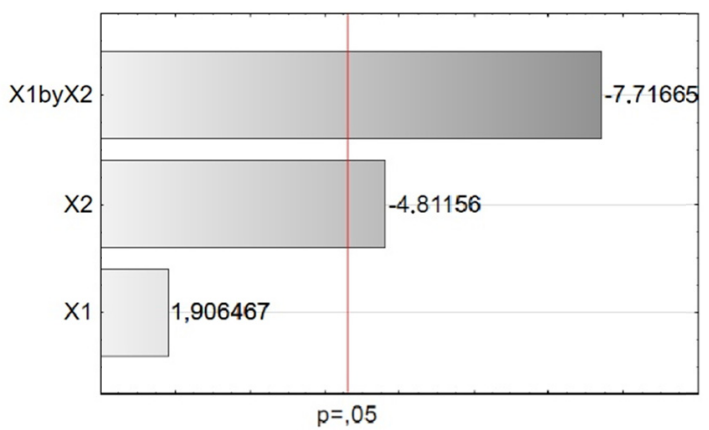

Figure 4. Pareto diagram of factors after ozonation for the 2-thiobarbituric acid test (mg MA kg FM) in samples of peanut grains (1) and oil (2) obtained from ozonized peanut grains (A) and grains in pod (B)

Lower values of substances that react with TBA (TBARS) were observed in untreated grains, indicating that ozone application influenced lipid oxidation (Table 3). Lipid oxidation can occur when $\mathrm{O}_{3}$ oxidizes unsaturated bonds of grain lipids (Khadre et al., 2001). In addition, the enzymatic system present in the grains degrades reserves of carbohydrates and lipids in the respiration, using $\mathrm{O}_{2}$ and releasing $\mathrm{CO}_{2}$. However, ozone application may have inhibited the respiratory process, resulting in the molecular $\mathrm{O}_{2}$ surplus and increasing the oxygen reactive species (ROS), which also caused a higher degradation in relation to the grains of the control treatment (Taiz \& Zeiger, 2017). The data obtained through this study, but not presented, showed higher $\mathrm{CO}_{2}$ values in control samples of peanut grains and grains in pod, confirming our hypothesis.

Ozone can react with water inside the cell and trigger ROS production, which can oxidize lipids, proteins, amino acids, nucleic acids, and lead to the production of other ROS. The interaction of ROS with the fatty acids present 
in the cell membrane generates a chain reaction known as lipid peroxidation (Heath, 2008).

The content of TBA was reduced as a function of the ozone application time, which can be explained by a change in the fatty acid profile of membranes. Linoleic (18:2) and linolenic acids (18:3) are the main fatty acids of the plant membrane (Taiz \& Zeiger, 2017) and their peroxidation results in the formation of the 4-hydroxy-2-nonenal (HNE) and malonaldehyde (MA), respectively (Møller, Jensen, \& Hansson, 2007). Peanut oil has a high oleic acid (18:1) content (Sarvamangala, Gowda, \& Varshney, 2011), which forms fewer degradation products reactive with TBA (Nawar, 1996). Initial membrane peroxidation may reduce the formation of MA at the end of the ozonation process and explain the reduction of TBA content since MA is the main product detected by this test. Scussel et al. (2011) observed that MA values decreased and remained constant during the storage of ozonized nuts due to ozone oxidation and attributed these results to the amount of oleic (monounsaturated) and linoleic (polyunsaturated) acids.

In addition, a higher TBARS content was observed in the analysis of grains in relation to the pure oil. This is also due to the character of the test, which can quantify other aldehydes from sugars, such as acetaldehyde and Maillard reaction compounds (Nawar, 1996), which are not formed in the extracted oil.

Therefore, the oxidative reactions originate from the double bonds present in fatty acid molecules, which make up the lipid fraction of food. In peanut grains, unsaturated fatty acids represent the major part of the lipid fraction, with a high possibility of occurring oxidative reactions in these grains due to the structure of their molecules (Sarvamangala et al., 2011).

\section{Conclusions}

The results of this study suggested that the longer the exposure time to $\mathrm{O}_{3}$ and the higher its concentration, the fungicidal effect is increased. These conditions corresponded to the ozone concentration of 50 ppm and exposure time of 60 minutes. However, this increase may cause leakage of exudates, directly related to the deterioration of the cell membrane. Therefore, this effect should be considered by processing industry in case of using higher concentrations. In addition, lipid degradation occurred at the cellular level, but differences in the peroxide index were not observed in ozonized grains.

\section{Acknowledgements}

The authors thank the Araucária Foundation for Support to Scientific and Technological Development of the State of Paraná and CAPES for financial support.

\section{References}

Abdel-Wahhab, M. A., Sehab, A. F., Hassanien, F. R., El-Nemr, Sh. E., Amra, H. A., \& Abdel-Alim, H. A. (2011). Efficacy of Ozone to Reduce Fungal Spoilage and Aflatoxin Contamination in Peanuts. International Journal of Nuts and Related Sciences, 4, 1-14. https://doi.org/10.1.1.835.1023\&rep=rep1\&type=pdf

Alencar, E. R., Faroni, L. R. D., Soares, N. F. F., Carvalho, M. C. S., \& Pereira, K. F. (2011). Effect of the ozonization process on the quality of peanuts and crude oil. Revista Brasileira de Engenharia Agrícola e Ambiental, 15, 154-160. https://doi.org/10.1590/S1415-43662011000200009

Alencar, E. R., Faroni, L. R. D., Soares, N. F. F., Silva, W. A., \& Carvalho, M. C. S. (2012). Efficacy of ozone as a fungicidal and detoxifying agent of aflatoxins in peanuts. Journal of the Science of Food and Agriculture, 92, 899-905. https://doi.org/10.1002/jsfa.4668

ANVISA. (1999). Regulamento técnico para fixação de identidade e qualidade de óleos e gorduras vegetais (Resolução nº 482, de 23 de set de 1999). Brasília: Agência Nacional de Vigilância Sanitária.

AOCS. (2009). Official methods and recommended practices (6th ed.). Champaign: American Oil Chemists' Society.

Beuchat, L. R., \& Cousin, M. A. (2001). Compendium of methods for the microbiological examination of foods. Washington: DC.

Chen, R., Ma, F., Li, P. W., Zhang, W., Ding, X. X., Zhang, Q., .. Xu, B. C. (2014). Effect of ozone on aflatoxins detoxification and nutritional quality. Food Chemistry, 146, 284-288. https://doi.org/ 10.1016/j.foodchem.2013.09.059

Chen, Y., Kong, Q., Chi, C., Shan, S., \& Guan, B. (2015). Biotransformation of aflatoxin $B_{1}$ and aflatoxin $\mathrm{G}_{1}$ in peanut meal by anaerobic solid fermentation of Streptococcus thermophilus and Lactobacillus delbrueckii subsp. Bulgaricus. International Journal of Food Microbiology, 211, 1-5. https://doi.org/10.1016/j.ijfood micro.2015.06.021 
Christ, D., Savi, G. D., \& Scussel, V. M. (2016). Effectiveness of ozone gas in raw and processed food for fungi and mycotoxin decontamination-A review. Journal of Chemical, Biological and Physical Sciences, 6, 326-348. https://doi.org/10.5923/j.fph.20170703.01

Cullen, P. J., Tiwari, B. K., O’Donnell, C. P., \& Muthukumarappan, K. (2009). Modelling approaches to ozone processing of liquid foods. Trends in Food Science \& Technology, 20, 125-136. https://doi.org/10.1016/ j.tifs.2009.01.049

Diao, E., Hou, H., Chen, B., Shan, C., \& Dong, H. (2013). Ozonolysis efficiency and safety evaluation of aflatoxin B1 in peanuts. Food and Chemical Toxicology, 55, 519-525. https://doi.org/10.1016/j.fct.2013. 01.038

Diao, E., Wang, J., Li, X., \& Wang, X. (2018). Patulin degradation in apple juice using ozone detoxification equipment and its effects on quality. Journal of Food Processing and Preservation, 42, 1-7. https://doi.org/ $10.1111 /$ jfpp. 13645

FAO. (1999). Codex standard for edible fats and oils not covered by individual standards. Retrieved from http://www.fao.org/docrep/004/y2774e/y2774e03.htm

Figueiredo Neto, A. F., Dantas, B. F., Silva, J. C., Olivier, N. C., \& Silva, M. F. (2012). Resistência ao fluxo de ar das vagens de amendoim com diferentes percentuais de impurezas. Nucleus, 9, 85-92. https://doi.org/ $10.3738 / 1982.2278 .673$

Granella, S. J., Christ, D., Werncke, I., Bechlin, T. R., \& Coelho, S. R. M. (2018). Effect of drying and ozonation process on naturally contaminated wheat seeds. Journal of Cereal Science, 80, 205-211. https://doi.org/ 10.1016/j.jcs.2018.03.003

Heath, R. L. (2008). Modification of the biochemical pathways of plants induced by ozone: What are the varied routes to change? Environmental Pollution, 155, 453-463. https://doi.org/10.1016/j.envpol.2008.03.010

Heslehurst, M. R. (1988). Quantifying initial quality and vigour of wheat seeds using regression analysis of conductivity and germination data from aged seeds. Seed Science and Technology, 16, 75-85.

Khadre, M. A., Yousef, A. E., \& Kim, J. G. (2001). Microbiological aspects of ozone applications in food: A review. JFS: Concise Reviews in Food Science, 66, 1242-1252. https://doi.org/10.1111/j.1365-2621.2001. tb15196.x

Mao, J., He, B., Zhang, L., Li, P., Zhang, Q., Ding, X., \& Zhang, W. (2016). A structure identification and toxicity assessment of the degradation products of aflatoxin $\mathrm{B}_{1}$ in peanut oil under $\mathrm{UV}$ irradiation. Toxins, 8 , 332-342. https://doi.org/10.3390/toxins8110332

MAPA. (2009). Manual de análise sanitária de sementes. Retrieved from https://www.abrates.org.br/files/ manual-de-analise-sanitaria-de-sementes.pdf

Martins, L. M., Sant'ana, A. S., Fungaro, M. H. P., Silva, J. J., Nascimento, M. S., Frisvad, J. C., \& Taniwaki, M. H. (2017). The biodiversity of Aspergillus section Flavi and aflatoxins in the Brazilian peanut production chain. Food Research International, 94, 101-107. https://doi.org/10.1016/j.foodres.2017.02.006

Mendez, F., Maier, D. E., Mason, L. J., \& Woloshuk, C. P. (2003). Penetration of ozone into columns of stored grains and effects on chemical composition and processing performance. Journal of Stored Products Research, 39, 33-44. https://doi.org/10.1016/S0022-474X(02)00015-2

Michaowicz, J., Posmyk, M. \& Duda, W. (2009). Chlorophenols induce lipid peroxidation and change antioxidant parameters in the leaves of wheat (Triticum aestivum L.). Journal of Plant Physiology, 166, 559-568. https://doi.org/10.1016/j.jplph.2008.09.011

Møller, I. M., Jensen, P. E., \& Hansson, A. (2007). Oxidative modifications to cellular components in plants. Annual Review of Plant Biology, 58, 459-481. https://doi.org/10.1146/annurev.arplant.58.032806.103946

Nawar, W. W. (1996). In O. R. Fennema (Ed.), Lipids. New York: Marcel Dekker.

Power, I. L., Dang, P. M., Sobolev, V. S., Orner, V. A., Powell, J. L., Lamb, M. C., \& Arias, R. S. (2017). Characterization of small RNA populations in non-transgenic and aflatoxin-reducing-transformed peanut. Plant Science, 257, 106-125. https://doi.org/10.1016/j.plantsci.2016.12.013

Rozado, A. F., Faroni, L. R. D., Urruchi, W. M. I., Guedes, R. N. C., \& Paes, J. L. (2008). Aplicação de ozônio contra Sitophilus zeamais e Tribolium castaneum em milho armazenado. Revista Brasileira de Engenharia Agrícola e Ambiental, 12, 282-285. https://doi.org/10.1590/S1415-43662008000300009 
Saalia, F. K., \& Phillips, R. D. (2011) Reduction of aflatoxins in peanut meal by extrusion cooking in the presence of nucleophiles. LWT-Food Science and Technology, 44, 1511-1516. https://doi.org/10.1016/j.lwt. 2011.02.012

Sahab, A. F., Hassanien, F. R., El-Nemr, S. E., Abdel-Alim, H. A., \& Abdel-Wahhab, M. A. (2013). Effect of ozone gaseous on aflatoxin degradation and fat and protein content in peanut seeds. Journal of Applied Sciences Research, 9, 2170-2175.

Sarvamangala, C., Gowda, M. V. C., \& Varshney, R. K. (2011). Identification of quantitative trait loci for protein content, oil content and oil quality for groundnut (Arachis hypogaea L.). Field Crops Research, 122, 49-59. https://doi.org/10.1016/j.fcr.2011.02.010

Scussel, V. M., Giordano, B. N., Simão, V., Manfio, D., Galvão, S., \& Rodrigues, M. N. F. (2011). Effect of oxygen-reducing atmospheres on the safety of packaged shelled Brazil nuts during storage. International Journal of Analytical Chemistry, 2011, 1-9. https://doi.org/10.1155/2011/813591

Silva, F. A. M., Borges, M. F. M., \& Ferreira, M. A. (1999). Métodos para avaliação do grau de oxidação lipídica e da capacidade antioxidante. Química Nova, 22, 94-103. https://doi.org/10.1590/S0100-4042199900 0100016

Taiz, L., \& Zeiger, E. (2017). Fisilogia e desenvolvimento vegetal (6th ed.). Porto Alegre: Artmed.

Tiwari, B. K., Brennan, C. S., Curran, T., Gallagher, E., Cullen, P. J., \& O’Donnel, C. P. (2010). Application of ozone in grain processing. Journal of Cereal Science, 51, 248-255. https://doi.org/10.1016/j.jcs.2010.01.007

Vieira, R. D., Tekrony, D. M., Egli, D. B., \& Rucker, M. (2001). Electrical conductivity of soybean seeds after storage in several environments. Seed Science and Technology, 29, 599-608.

Wang, X., Lien, K., \& Ling, M. (2018). Probabilistic health risk assessment for dietary exposure to aflatoxin in peanut and peanut products in Taiwan. Food Control, 91, 372-380. https://doi.org/10.1016/j.foodcont. 2018.04.021

\section{Copyrights}

Copyright for this article is retained by the author(s), with first publication rights granted to the journal.

This is an open-access article distributed under the terms and conditions of the Creative Commons Attribution license (http://creativecommons.org/licenses/by/4.0/). 